\title{
PENGARUH TINGKAT SUKU BUNGA, INFLASI, DAN KREDIT BERMASALAH TERHADAP PENYALURAN KREDIT UMKM DI INDONESIA
}

\author{
Hanif Artafani Biasmara \\ Program Studi Manajemen Bisnis Telekomunikasi \& Informatika, Telkom University \\ hanifartafani@student.telkomuniversity.ac.id
}

Masuk : 11-04-2021, revisi : 11-05-2021, diterima untuk diterbitkan : 20-05-2021

\begin{abstract}
Banks as intermediary institutions have a role in extending credit to the public. One of the loans provided by banks to the public is credit for Micro, Small, and Medium Enterprises (MSMEs). This research was conducted to analyze several factors consisting of Bank Indonesia (BI) interest rates or BI Rate, inflation, and bad credit or NPL that would affect MSME credit distribution. The research period is from 2011 to 2020. While the object sample consists of four banking groups, namely State-Owned Banks, Regional Development Banks, Foreign Exchange Commercial Banks, and Joint Venture Banks and Foreign Owned Banks. Where this research is a quantitative study using secondary data. Data processing using Panel Data Regression through Stata 16. The results obtained indicate that bad credit has a significant positive effect on MSME credit. Meanwhile, interest rates and inflation did not have a significant effect on MSME credit.
\end{abstract}

Keywords: MSME credit, BI Rate, Inflation, NPL

Abstrak: Bank sebagai lembaga perantara memiliki peranan dalam menyalurkan kredit kepada masyarakat. Salah satu kredit yang diberikan oleh bank kepada masyarakat adalah kredit Usaha Mikro Kecil Menengah (UMKM). Penelitian ini dilakukan untuk menganalisis beberapa faktor yang terdiri atas tingkat suku bunga Bank Indonesia (BI) atau BI Rate, inflasi, dan kredit bermasalah atau NPL, akan pengaruhnya terhadap penyaluran kredit UMKM. Periode penelitian yaitu tahun 2011 hingga tahun 2020. Sedangkan sampel objek terdiri atas empat kelompok bank yaitu Bank Persero, Bank Pembangunan Daerah, Bank Swasta Nasional, dan Bank Asing atau Campuran. Dimana penelitian ini merupakan penelitian kuantitatif dengan menggunakan data sekunder. Data diolah dengan menggunakan metode Regresi Data Panel melalui perangkat lunak Stata 16. Hasil yang diperoleh yaitu menunjukkan bahwa kredit bermasalah memiliki pengaruh signifikan positif terhadap kredit UMKM. Sedangkan tingkat suku bunga dan inflasi berpengaruh namun tidak signifikan terhadap kredit UMKM.

Kata Kunci: Kredit UMKM, BI Rate, Inflasi, NPL

\section{PENDAHULUAN}

\section{Latar Belakang}

Bank merupakan badan yang dikenal sebagai lembaga dengan fungsi menghimpun dana dari nasabah dan akan didistribusikan kepada pihak-pihak yang mengajukan permohonan untuk memperoleh dana (Ismanto et al., 2019). Bank-bank di Indonesia memiliki segmentasi dalam menyalurkan dananya yang mana terdiri atas berbagai macam pihak, salah satunya adalah Usaha Mikro Kecil Menengah (UMKM). Bank Indonesia, sebagai bank sentral telah mengatur minimum total kredit untuk UMKM sebesar $20 \%$ dari total kredit keseluruhan. Sehingga dengan adanya penyaluran kredit kepada UMKM yang disediakan oleh bank-bank di Indonesia, diharapkan perkembangan UMKM di Indonesia juga akan semakin pesat.

Perhatian pemerintah dalam penyaluran kredit bagi UMKM di Indonesia, didasari atas peran UMKM dalam mendorong pertumbuhan perekonomian Indonesia (Abduh, 2017). UMKM sendiri dapat dikatakan sebagai penopang perekonomian sewaktu Indonesia mengalami krisis moneter pada tahun 1998. Dimana di tengah keadaan perekonomian yang 
sedang terpuruk, UMKM dapat bertahan pada kondisi tersebut. Sehingga UMKM menjadi industri yang dapat terus tumbuh berkelanjutan dan berkontribusi terhadap perekonomian Indonesia.

Kredit UMKM yang disalurkan oleh perbankan di Indonesia dalam sepuluh tahun terakhir menunjukkan perkembangan dengan kecenderungan naik seperti pada Gambar 1 di bawah. Pada tahun 2019 menjadi penyaluran total kredit UMKM tertinggi. Hal ini menunjukkan bahwa industri UMKM di Indonesia juga semakin berkembang. Namun semakin berkembangnya total kredit UMKM yang tersalurkan juga akan dipengaruhi oleh beberapa faktor, seperti tingkat suku bunga atau BI Rate, inflasi, dan kredit bermasalah atau NPL.

\section{Gambar 1}

\section{Grafik Perkembangan Total Kredit UMKM}

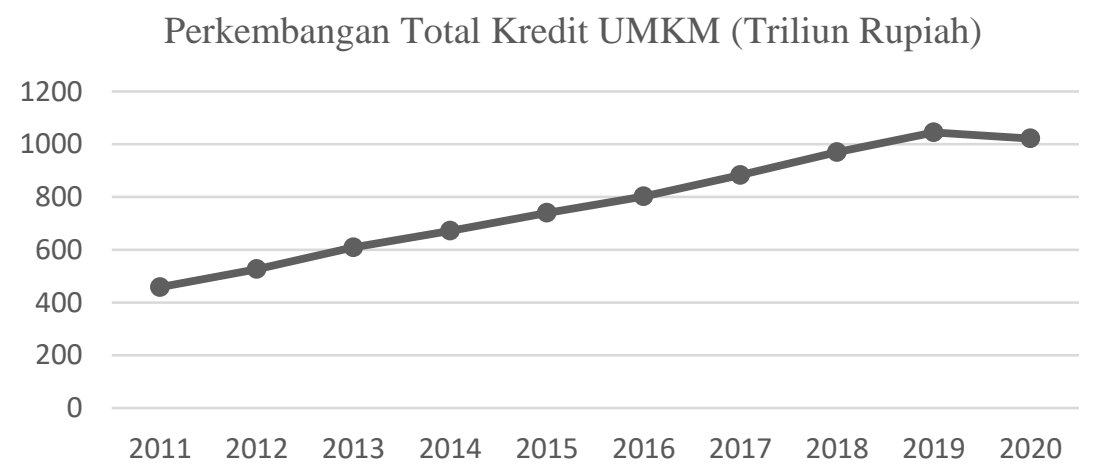

Sumber: Otoritas Jasa Keuangan (2020)

Penelitian yang dilakukan oleh Kaunang (2013) dan Soekapdjo (2019), mengungkapkan bahwa tingkat suku bunga BI atau BI rate memiliki pengaruh signifikan terhadap total kredit UMKM. Sedangkan menurut Ratnasari dan Soesatyo (2016), BI rate tidak memiliki pengaruh signifikan. Faktor selanjutnya yaitu inflasi, yang mana menurut Hidayat (2018) dan Soekapdjo (2019) memiliki pengaruh signifikan terhadap total kredit UMKM. Namun berdasarkan penelitian Ratnasari dan Soesatyo (2016), inflasi tidak memiliki pengaruh signifikan terhadap total kredit UMKM. Lalu untuk faktor berikutnya yaitu kredit bermasalah atau NPL yang memiliki pengaruh signifikan terhadap total kredit UMKM berdasarkan penelitian oleh Kaunang (2013), Hidayat (2018), serta Ratnasari dan Soesatyo (2016).

\section{Tujuan Penelitian}

Berdasarkan penjabaran dalam latar belakang dan terdapatnya beberapa perbedaan hasil penelitian terdahulu, timbul ketertarikan bagi penulis untuk meneliti mengenai pengaruh tingkat suku bunga BI, inflasi, dan kredit bermasalah terhadap penyaluran kredit UMKM oleh kelompok perbankan di Indonesia. Dimana melalui penelitian ini, diharapkan dapat mengidentifikasi faktor-faktor yang memiliki pengaruh signifikan maupun tidak signifikan terhadap total kredit UMKM dengan periode waktu tahun 2011 hingga tahun 2020. Penelitian ini dimaksudkan untuk memperkuat teori yang sudah ada, maupun memberikan hasil yang berbeda untuk dijadikan referensi baru.

\section{TINJAUAN PUSTAKA Kredit UMKM}

Pemberian kredit atau pembiayaan terhadap UMKM di Indonesia, dimaksudkan untuk menguatkan perekonomian negara. Sehingga pemerintah memberikan akses bagi pelaku UMKM untuk memperoleh pemberian kredit. Melalui Peraturan Bank Indonesia No. 17/12/PBI/2015 setiap Bank Umum diwajibkan untuk menyediakan dua puluh persen kredit UMKM dari total kredit yang diberikan (Wuryandani et al., 2018).

\section{Pengaruh Tingkat Suku Bunga Bank Indonesia (BI)}

Setiap terjadi kenaikan suku bunga, akan memberikan pengaruh terhadap penyaluran kredit. Dimana kredit UMKM yang disalurkan akan semakin turun (Soekapdjo, 2019). Hal ini 
bagi pemilik UMKM merupakan suatu keuntungan yang mana pengembalian kredit kepada perbankan akan menjadi lebih kecil (Kaunang, 2013).

$\mathrm{H}_{1}$ : Tingkat suku bunga memiliki pengaruh signifikan terhadap kredit UMKM.

\section{Pengaruh Inflasi}

Inflasi yang dilihat dari Indeks Harga Konsumen, jika terjadi kenaikan pada inflasi akan memberikan pengaruh terhadap kredit UMKM. Dimana akan terjadi penurunan dalam kredit UMKM yang disalurkan (Soekapdjo, 2019). Hasil mengenai pengaruh signifikan inflasi terhadap kredit UMKM juga diungkapkan oleh Hidayat (2018).

$\mathrm{H}_{2}$ : Inflasi memiliki pengaruh signifikan terhadap kredit UMKM.

\section{Pengaruh Kredit Bermasalah}

Kredit bermasalah atau yang dikenal dengan sebutan Non-Performing Loan (NPL) memiliki pengaruh terhadap pemberian kredit UMKM. Jika nilai NPL tinggi, maka perbankan akan lebih berhati-hati dalam menyalurkan kredit. Sehingga akan menurunkan total kredit UMKM yang diberikan (Hidayat, 2018). Hal serupa juga diperoleh oleh Kaunang (2013) serta Ratnasari dan Soesatyo (2016).

$\mathrm{H}_{3}$ : Kredit bermasalah memiliki pengaruh signifikan terhadap kredit UMKM.

\section{Kerangka Pemikiran}

Berdasarkan penjelasan dan hipotesis yang diajukan, kerangka pemikiran disajikan untuk memberikan gambaran mengenai penelitian ini. Dimana terdapat tiga variabel bebas yaitu tingkat suku bunga BI, inflasi, dan kredit bermasalah. Sedangkan variabel terikat yaitu kredit UMKM. Berikut merupakan kerangka pemikiran dalam penelitian ini yang disajikan dalam Gambar 2.

\section{Gambar 2}

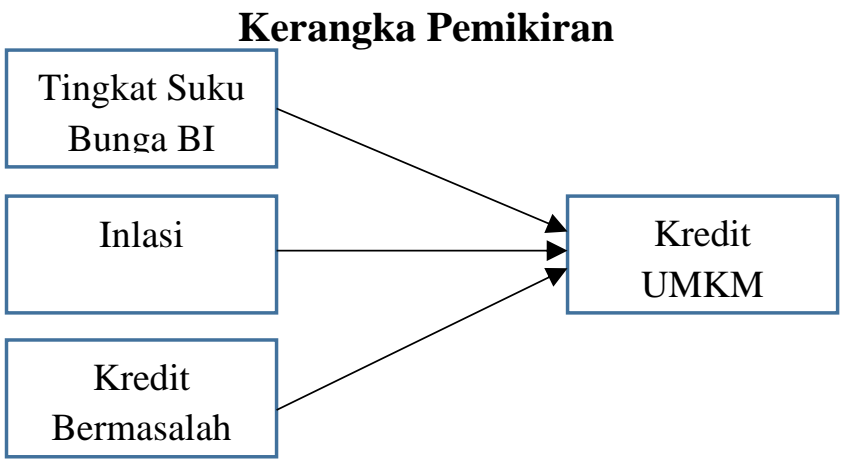

Sumber: Hasil Olahan Peneliti (2021)

\section{METODOLOGI PENELITIAN}

Penelitian ini merupakan penelitian kuantitatif karena menggunakan data-data yang berupa angka. Dimana data yang digunakan merupakan data sekunder, yaitu data yang telah diolah oleh pihak pertama dan telah dipublikasikan (Suryani \& Hendryadi, 2016). Data total kredit UMKM dan kredit bermasalah (NPL) diperoleh melalui laporan perbankan yang dipublikasikan oleh Otoritas Jasa Keuangan sejak tahun 2011-2020. Sedangkan data tingkat suku bunga (BI rate) dan inflasi diperoleh dari laman Badan Pusat Statistik dengan periode data dari tahun 2011 hingga tahun 2020. Sedangkan sampel objek terdiri atas empat kelompok bank yaitu Bank Persero, Bank Pembangunan Daerah, Bank Swasta Nasional, dan Bank Asing atau Campuran. Selanjutnya data akan diolah dengan menggunakan metode Regresi Data Panel yang merupakan gabungan antara data cross-section dan time-series (Suryani \& Hendryadi, 2016). Terdapat tiga model dalam data panel yaitu Common Effect Model, Fixed Effect Model, dan Random Effect Model. Dimana terdapat tiga pengujian model, yaitu uji Chow, uji Hausman, dan uji Lagrange Multiplier. Setelah itu, hasil regresi dengan pendekatan model terpilih akan menyajikan Analisis Koefisien Determinasi $\left(\mathrm{R}^{2}\right)$, uji $\mathrm{F}$ (simultan), dan uji hipotesis melalui uji t (parsial). 


\section{HASIL DAN KESIMPULAN \\ Hasil}

Sebelum dilakukan pengujian hipotesis, dilakukan pengujian model untuk memilih model terbaik. Pada pengujian pertama yang dilakukan yaitu uji Chow untuk menguji antara Common Effect Model dan Fixed Effect Model. Dimana dalam uji Chow, diperoleh nilai Prob>F sebesar 0.0001. Nilai yang diperoleh menunjukkan bahwa Prob>F lebih kecil dari 0.05. Sehingga pada uji Chow, model yang terpilih yaitu Fixed Effect Model. Pengujian yang kedua adalah uji Hausman untuk menguji antara Fixed Effect Model dan Random Effect Model. Hasil yang diperoleh dari pengujian ini yaitu nilai Prob>chi2 sebesar 0.6597. Hal menunjukkan bahwa nilai tersebut lebih besar dari 0.05. Sehingga model yang terpilih pada pengujian ini adalah Random Effect Model. Lalu, pengujian ketiga yaitu uji Lagrange Multiplier untuk menguji antara Common Effect Model dan Random Effect Model. Hasil yang diperoleh yaitu nilai Prob>chibar2 sebesar 0.0000. Sehingga nilai tersebut lebih kecil dari 0.05. Maka model yang terpilih yaitu Random Effect Model sebagai model terbaik.

Setelah model terbaik terpilih yaitu Random Effect Model, selanjutnya hasil regresi diperoleh. Sebelum membahasa hasil pengujian hipotesis yaitu uji t atau parsial, dilakukan dua pengujian yang terdiri atas Analisis Koefisien Determinasi $\left(\mathrm{R}^{2}\right)$ dan uji F. Pada hasil Analisis Koefisien Determinasi $\left(\mathrm{R}^{2}\right)$ diperoleh hasil sebesar 0.8901. Hal menunjukkan bahwa variabel bebas dapat menjelaskan variabel terikat sebesar $89.01 \%$, dan sisanya dapat dijelaskan oleh variabel lain. Lalu, untuk uji $\mathrm{F}$ atau simultan diperoleh nilai Prob>chi2 sebesar 0.0000. Hal ini berarti nilai tersebut lebih kecil dari 0.05. Maka seluruh variabel bebas yaitu tingkat suku bunga BI, inflasi, dan kredit bermasalah, secara bersama-sama memiliki pengaruh signifikan terhadap total kredit UMKM yang disalurkan. Sehingga dalam hal ini, perbankan dalam menyalurkan kredit UMKM harus selalu mengantisipasi dan mengukur keadaan ekonomi dan kinerja perbankan. Prinsip kehati-hatian yang diterapkan oleh perbankan dalam penyaluran kredit UMKM, diharapkan dapat menjaga kelancaran pengembalian kredit.

Pada pengujian hipotesis atau uji t, apabila nilai $\mathrm{P}>\mathrm{z}$ lebih kecil dari 0.05, maka variabel bebas memiliki pengaruh signifikan secara parsial terhadap variabel terikat. Sedangkan, apabila nilai $\mathrm{P}>\mathrm{z}$ lebih besar dari 0.05 , maka variabel bebas berpengaruh namun tidak signifikan. Hasil pengujian hipotesis tersaji dalam Tabel 1 di bawah.

\section{Tabel 1}

Hasil Uji Hipotesis

\begin{tabular}{ccccccc}
\hline Kredit & Coef. & Std. Err. & $\mathrm{Z}$ & $\mathrm{P}>\mathrm{z}$ & \multicolumn{2}{c}{ [95\% Conf. Interval] } \\
\cline { 2 - 7 } BIRate & 2.159043 & 8.985716 & 0.24 & 0.810 & -1.545264 & 1.977072 \\
Inflasi & 1.321351 & 5.520787 & 0.24 & 0.811 & -9.499193 & 1.214189 \\
NPL & 2.806398 & 3.156746 & 8.89 & 0.000 & 2.187687 & 3.425109 \\
cons & -2.264485 & 5.821091 & -0.39 & 0.697 & -1.367361 & 9.144644 \\
\hline
\end{tabular}

Sumber: Hasil Olahan Peneliti (2021)

Variabel bebas yang pertama yaitu tingkat suku bunga BI atau BI rate. Pada hasil pengujian, diperoleh nilai $\mathrm{P}>\mathrm{Z}$ sebesar 0.810 . Hal ini menunjukkan bahwa nilai tersebut lebih besar dari 0.05. Sehingga pada pengujian ini, variabel tingkat suku bunga BI berpengaruh namun tidak signifikan terhadap kredit UMKM. Maka, hipotesis yang telah diajukan yaitu $\mathrm{H}_{1}$ ditolak. Tidak signifikannya pengaruh tingkat suku bunga BI terhadap total kredit UMKM yang disalurkan oleh perbankan dapat terjadi karena perkembangan total kredit UMKM yang disalurkan oleh perbankan selalu mengalami kecenderungan untuk naik. Sedangkan tingkat suku bunga BI sendiri dalam sepuluh tahun terakhir mengalami perkembangan yang fluktuatif. Hasil penelitian yang sama juga diungkapkan oleh Ratnasari dan Soesatyo (2016), bahwa tingkat suku bunga BI berpengaruh tetapi tidak signifikan terhadap penyaluran kredit UMKM. Hal ini dikarenakan pemerintah telah berperan dalam memutuskan proporsi suku bunga kredit, terlebih pada kredit UMKM. Peran pemerintah dalam memutuskan proporsi bunga yang diterapkan, bertujuan untuk dapat memajukan penyaluran dana berupa kredit kepada pelaku UMKM sehingga dapat berkembang. Hasil penelitian yang diperoleh ini tidak sejalan dengan 
penelitian yang dilakukan oleh Kaunang (2013) dan Soekapjo (2019) dengan hasil yang menyatakan tingkat suku bunga BI atau BI rate memiliki pengaruh signifikan terhadap total kredit UMKM yang disalurkan.

Pada Tabel 1, didapatkan bahwa variabel inflasi memiliki nilai $\mathrm{P}>\mathrm{Z}$ sebesar 0.811 . Nilai tersebut menunjukkan lebih besar dari 0.05. Sehingga pada pengujian ini, dalam sepuluh tahun terakhir inflasi berpengaruh namun tidak signifikan terhadap total kredit UMKM yang disalurkan. Maka, hipotesis yang telah diajukan sebelumnya yaitu $\mathrm{H}_{2}$ ditolak. Pada penelitian ini, tidak adanya pengaruh signifikan oleh inflasi terhadap total kredit UMKM memiliki pola yang sama dengan tidak signifikannya pengaruh tingkat suku bunga BI. Hal ini dikarenakan inflasi sejak tahun 2011 hingga tahun 2020 selalu mengalami fluktuasi. Sedangkan total kredit UMKM yang tersalurkan selalu cenderung mengalami kenaikan. Hasil yang serupa juga diungkapkan oleh Ratnasari dan Soesatyo (2016), dimana pada penelitian yang mereka lakukan pada periode tahun 2011 hingga tahun 2015, menunjukkan bahwa variabel inflasi juga mengalami fluktuasi dan total kredit UMKM semakin bertambah. Kejadian tersebut, ditengarai karena pelaku UMKM tetap membutuhkan dana berupa kredit UMKM walaupun inflasi sedang tinggi. Hasil penelitian ini tidak sejalan dengan penelitian yang dilakukan oleh Hidayat (2018) dan Soekapdjo (2019) yang menyatakan inflasi berpengaruh dan signifikan terhadap total kredit UMKM yang disalurkan.

Variabel terakhir yaitu kredit bermasalah yang dilihat dari nilai NPL, akan pengaruhnya terhadap total kredit UMKM. Hasil regresi menunjukkan bahwa nilai $\mathrm{P}>\mathrm{z}$ sebesar 0.000. Nilai tersebut berarti lebih kecil dari 0.05. Maka, hal ini menunjukkan bahwa kredit bermasalah memiliki pengaruh signifikan terhadap total kredit UMKM yang disalurkan. Nilai koefisien yang diperoleh sebesar 2.806398, dimana nilai tersebut menunjukkan arah hubungan yang positif. Hal ini berarti jika terdapat kenaikan pada nilai kredit bermasalah, maka total kredit yang diberikan akan ikut naik. Hasil penelitian ini tentunya bertolak belakang dengan teori yang diajukan oleh beberapa peneliti sebelumnya seperti Ratnasari dan Soesatyo (2016). Dimana arah hubungan pada kredit bermasalah pada penelitian yang dilakukan menunjukkan arah hubungan yang negatif. Jika nilai kredit bermasalah naik, maka bank akan lebih berhatihati dalam menyalurkan kredit UMKM yang diberikan. Sehingga dapat mengurasi risiko kredit. Penelitian yang sama mengenai hasil berpengaruhnya nilai kredit bermasalah terhadap total kredit yang disalurkan juga diperoleh pada penelitian Kaunang (2013) dan Hidayat (2018).

\section{Kesimpulan}

Penelitian yang telah dilakukan dapat ditarik beberapa kesimpulan. Pada penelitian ini, didapatkan hasil bahwa dua variabel yaitu tingkat suku bunga BI dan inflasi memiliki pengaruh namun tidak signifikan terhadap total kredit UMKM yang disalurkan. Lalu pada variabel kredit bermasalah menunjukkan memiliki pengaruh signifikan terhadap total kredit UMKM. Hal ini berarti perbankan harus menjaga nilai kredit bermasalah supaya tidak tinggi dan menerapkan prinsip kehati-hatian dalam menyalurkan kredit UMKM, namun tetap berkontribusi selalu dalam menyalurkan kredit bagi modal UMKM. Saran bagi peneliti selanjutnya, untuk dapat meneliti lebih dalam mengenai faktor-faktor yang berpengaruh terhadap penyaluran kredit UMKM. Peneliti selanjutnya dapat menambah periode waktu penelitian dan meneliti pengaruh dari variabel lain yang tidak digunakan dalam penelitian ini.

\section{DAFTAR PUSTAKA}

Abduh, T. (2017). Strategi internasionalisasi UMKM. CV Sah Media.

Hidayat, R. A. L. (2018). Pengaruh variabel rasio keuangan dan makroekonomi terhadap pemberian kredit sektor UMKM oleh perbankan di Indonesia. Jurnal Manajemen Dan Pemasaran Jasa, 9(2), 253-268. https://doi.org/10.25105/jmpj.v9i2.2035

Ismanto, H., Widiastuti, A., Muharam, H., Pangestuti, I. R. D., \& Rofiq, F. (2019). Perbankan dan Literasi Keuangan (1st ed.). Deepublish. 
Kaunang, G. (2013). Tingkat suku bunga pinjaman dan kredit macet pengaruhnya terhadap permintaan kredit UMKM di Indonesia. Jurnal Riset Ekonomi, Manajemen, Bisnis Dan Akuntansi, 1(3), 920-930. https://doi.org/10.35794/emba.v1i3.2297

Otoritas Jasa Keuangan. (2020). Statistik perbankan Indonesia. https://www.ojk.go.id/id/kanal/perbankan/data-dan-statistik/statistik-perbankanindonesia/Documents/Pages/Statistik-Perbankan-Indonesia---Desember-2020/Statistik Perbankan Indonesia Des 2020.pdf

Ratnasari, N., \& Soesatyo, Y. (2016). Variabel-variabel yang mempengaruhi penyaluran kredit kepada UMKM oleh perbankan di Indonesia tahun 2011-2015. Jurnal Pendidikan Ekonomi (JUPE), 4(3), 1-10. https://doi.org/10.26740/jupe.v4n3.p\%25p

Soekapdjo. (2019). Determinasi penyaluran kredit UMKM di Provinsi Kalimantan Timur. Forum Ekonomi, 21(2), 226-234. https://doi.org/10.29264/jfor.v21i2.4652

Suryani, \& Hendryadi. (2016). Metode riset kuantitatif: Teori dan aplikasi pada penelitian bidang manajemen dan ekonomi Islam. Prenada Media Group.

Wuryandani, D., Harefa, M., Meilani, H., Mangeswuri, D. R., \& Silalahi, S. A. F. (2018). Pengembangan kewirausahaan untuk pemberdayaan UKM daerah. In Electronic Book. Yayasan Pustaka Obor Indonesia.

https://www.google.co.id/books/edition/Pengembangan_Kewirausahaan_untuk_Pember d/6POiDwAAQBAJ?hl=id\&gbpv=0 